\title{
ANALISIS CURRENT RATIO, DEBT TO TOTAL ASSET RATIO,DEBT TO EQUITY RATIO, DAN NET PROFIT MARGIN TERHADAP HARGA SAHAM PADA PERUSAHAAN FOOD AND BEVERAGE YANG TERDAFTAR DI BURSA EFEK INDONESIA
}

\author{
Suvianto Wangdra \\ Dosen Program Studi Akuntansi, Universitas Putera Batam \\ email: suvianto@puterabatam.ac.id
}

\begin{abstract}
The aim of this research is to determine the effect of the variables Current Ratio, Debt to Total Asset Ratio, Debt to Equity Ratio, and Net Profit Margin to the stock prices of food and beverage companies listed on the Indonesia Stock Echange for the period 2013-2017. The population in this research included food and beverage companies listed on the Indonesia Stock Exchange. The sampling technique on this research used was Purposive Sampling based on the following criteria: (1) Food and beverage companies listed on the Indonesia Stock Exchange, (2) Food and beverage companies listed on the Indonesia Stock Exchange which provide complete annual financial reports from 2013-2017, (3) Food and beverage companies that provide financial statements in Rupiah. By using purposive sampling, a total sample of 12 companies were acquired with a total of 60 observations. The data analysis technique used in this research is multiple linear regression analysis. Result show that Current Ratio, Debt to Total Asset Ratio,and Debt to Equity Ratio don't have significant effect in stock prices of companies. Meanwhile, Net Profit Margin has a significant effect in stock prices of companies.
\end{abstract}

Keyword: Stock Price; Current Ratio; Debt to Total Asset Ratio; Debt to Equity Ratio; Net Profit Margin.

\section{PENDAHULUAN}

Di era reformasi ini, kemajuan ekonomi di Indonesia mulai berkembang pesat disebabkan melimpahnya tenaga kerja dan sarana infrastruktur yang membuat kondisi ekonomi di Indonesia mulai membaik dari periode-periode sebelumnya. Akan tetapi, daya saing yang lemah dan iklim investasi yang rendah menjadi salah satu faktor merosotnya pertumbuhan ekonomi Indonesia. Seperti halnya nilai tukar rupiah yang rendah disertai tingkat inflasi yang tinggi. Nilai rupiah kian melemah dari dollar Amerika Serikat saat ini, bahkan ada beberapa bank yang telah menjual nilai rupiah tersebut Rp 15.000,- per dollar Amerika Serikat. Hal ini disebabkan oleh krisis hutang ekonomi dari perusahaan swasta yang mendorong tekanan rupiah mencapai tingkat depresiasi yang tinggi.

Untuk meningkatkan stabilitas pertumbuhan ekonomi di Indonesia dibutuhkan dana yang cukup. Dana tersebut dapat berupa investasi dalam negeri maupun investasi luar negeri. Investasi dapat meningkatkan kesejahteraan hidup masyarakat baik golongan kalangan bawah, menengah maupun kalangan atas, dan juga dapat meningkatkan pertumbuhan ekonomi suatu negara. Oleh karena itu, adanya investasi dapat meminimalkan resiko perekonomian Indonesia yang merosot akibat utang perusahaan maupun pemerintah. Lokasi berinvestasi yang tepat adalah di pasar modal dikarenakan peran dari pasar modal sangat penting dalam mempercepat pembangunan suatu negara.

Sarana yang dapat digunakan oleh para investor untuk berinvestasi yaitu saham. Saham menunjukkan kepemilikan dana seseorang yang ditanamkan dengan tujuan memperoleh keuntungan di masa mendatang. Ketika menanamkan saham, terjadi permintaan dan penawaran yang dipengaruhi oleh faktor penting yaitu tingkat harga saham (Junaeni 2017). Seringkali terjadi pelanggaran-pelanggaran hukum di pasar modal karena umumnya penentuan nilai saham 
suatu perusahaan tidak didasari dengan teknik analisis rasio keuangan melainkan dari pemikiran orang-orang pintar di pasar modal itu sendiri.

Mereka menentukan harga saham tersebut tinggi dan rendah sesuai keinginan sendiri dalam rentang waktu tertentu untuk membuat citra nama perusahaan tersebut baik di mata investor. Selain itu, mereka juga menyebarkan informasi palsu yang menerangkan kondisi perusahaan tersebut yang sangat bagus untuk mendukung manipulasi pasar. Untuk menilai kondisi keuangan dan prestasi suatu perusahaan bukanlah sesuai keinginan sendiri melainkan diperlukan beberapa pengukuran. Pengukuran yang dimaksud ialah rasio keuangan.

Banyak perusahaan disebabkan oleh krisis ekonomi yang memburuk sehingga tidak dapat memenuhi kewajibannya seperti membayar hutang. Faktor lainnya yaitu Current Ratio yang diperhitungkan tidak sesuai dengan kewajiban akrual yang sedang dialami perusahaan saat itu. Selain itu, kondisi perusahaan tidak likuid dapat menghambat pertumbuhan ekonomi suatu perusahaan sehingga terlibat masalah seperti hutang menumpuk. Untuk meminimalkan hal tersebut, perusahaan harus memiliki jumlah asset atau investasi yang dapat segera berubah menjadi kas untuk memenuhi kewajibannya dengan memperhitungkan Current Ratio. Jika Current Ratio perusahaan memenuhi kriteria yang sangat bagus atau standar $200 \%$ menandakan bahwa perusahaan berada dalam kondisi likuid yang tentunya akan berdampak positif bagi perusahaan.

Selain dilihat dari tingkat likuidasi perusahaan, prestasi dan kondisi perusahaan juga dapat diketahui dengan kemampuan perusahaan membayar kewajibannya. Debt to Total Asset Ratio merupakan salah satu rasio yang diterapkan untuk mengukur kemampuan perusahaan tersebut. Segi pengukuran Debt to Total Asset Ratio menunjukkan nilai perimbangan antara total hutang dengan total aktiva. Semakin besar hutang yang dimiliki perusahaan tersebut dapat ditunjukkan dengan tingginya rasio ini. Suatu perusahaan yang memiliki aktiva dan modal yang cukup untuk melunasi hutangnya maka dapat dikatakan bahwa perusahaan tersebut solvabel.

Di sisi lain, rasio Debt to Equity Ratio juga diperlukan dalam mengukur solvabilitas perusahaan. Perkiraan perbandingan antara hutang dengan ekuitas perusahaan dalam aktivitas pendanaan ditunjukkan oleh rasio Debt to Equity Ratio. Sama halnya dengan Debt to Total Asset Ratio, semakin besar kewajiban yang harus dipenuhi oleh perusahaan tersebut maka nilai rasio ini akan semakin besar. Selain itu, Debt to Equity Ratio dijadikan sebagai patokan yang menunjukkan batas perusahaan dalam meminjam dana kepada pihak lain. Debt to Equity Ratio yang tinggi dapat memungkinkan perusahaan tidak dapat menarik tambahan modal dari para investor.

Seringkali kita sebagai investor mengalami kesulitan dalam menanamkan modal dimana harus memilih perusahaan yang menarik dengan prestasi yang bagus. Jika dana yang dimiliki terbatas tentunya harus memilih salah satu diantara lainnya yang menarik. Oleh karena itu, untuk mempermudah dalam pengambilan keputusan investasi, dibutuhkan rasio profitabilitas yaitu Net Profit Margin yang dikatakan sebagai margin untuk menilai persentase laba terhadap penjualan pada perusahaan tersebut. Dengan adanya Net Profit Margin, investor dapat menentukan perusahaan mana yang dapat menghasilkan keuntungan di masa mendatang. Dari pandangan para investor, tingkat profitabilitas perusahaan merupakan kunci utama yang mencerminkan kesanggupan perusahaan dalam memperoleh laba.

\section{TINJAUAN PUSTAKA}

Perusahaan yang mencapai prestasi yang baik dapat memikat para investor untuk berinvestasi dikarenakan harga saham merupakan salah satu bagian penting yang mencerminkan nilai suatu perusahaan. Harga saham ditentukan berdasarkan nilai intrinsik, nilai pasar dan nilai buku (Jogiyanto 2010). Indikator keberhasilan dalam pengelolaan perusahaan salah satunya adalah harga saham. Perusahaan dengan harga saham yang tinggi menunjukkan bahwa perusahaan tersebut berhasil dalam mengembangkan usaha untuk mencapai tujuan (Zuliarni 2012). Meningkatnya harga saham akan meningkatkan kepercayaan para investor terhadap perusahaan. Jumlah permintaan dan penawaran juga dapat mencerminkan tingkat harga saham. 
Current Ratio menggambarkan seberapa jauh aktiva lancar yang diperoleh untuk membentangi kewajiban lancar perusahaan. Perusahaan dapat memiliki kemampuan tinggi dalam menyelesaikan kewajibannya jika aktiva lancar dengan kewajiban lancar menunjukkan perbandingan yang besar (Harahap 2016). Current Ratio dinilai dalam bentuk desimal yang menunjukkan berapa banyak aktiva lancar yang diperlukan untuk menutupi tiap rupiah kewajiban lancar perusahaan tersebut sehingga dapat diketahui seberapa jauh kemampuan perusahaan membayar kewajiban jangka pendeknya (L.M.Samryn, S.E., Ak. 2015). Rasio ini dapat berupa kali atau persentase. Apabila Current Ratio berada pada 1:1 atau persentase 100\% ini menggambarkan aktiva lancar dapat membentangi semua kewajiban lancar perusahaan. Begitu pula sebaliknya, aktiva lancar jauh di atas kewajiban lancar apabila tingkat Current Ratio berada di atas 1 atau di atas $100 \%$.

Menurut (Hery S.E., M.Si., RSA. 2015) Perbandingan antara total hutang termasuk seluruh hutang jangka pendek dan jangka panjang terhadap total aktiva yang dimiliki perusahaan dapat diukut menggunakan rasio Debt to Total Asset Ratio. Menurut (Sujarweni 2017) rasio Debt to Total Asset Ratio juga menandakan berapa unit dari keseluruhan aktiva yang digunakan. Bisa juga dikatakan seberapa banyak porsi hutang jika dibandingkan dengan aktiva. Porsi hutang atas aktiva harus seminimal mungkin untuk memperoleh rasio yang aman (solvable).

Perbandingan total hutang termasuk hutang jangka panjang dan jangka pendek terhadap total ekuitas suatu perusahaan dapat diukur menggunakan rasio Debt to Equity Ratio (Hery S.E., M.Si., RSA. 2015). Menurut (Sujarweni 2017) Rasio Debt to Equity Ratio merupakan suatu perbandingan hutang dengan ekuitas yang dimiliki perusahaan pada aktivitas pendanaan serta menggambarkan kapabilitas modal yang dimiliki. Rasio Debt to Equity Ratio menunjukkan seberapa jauh hutang terhadap pihak luar dapat ditutupi dengan modal yang dimiliki. Menurut (Harahap 2016) untuk keamanan pihak luar, modal yang dimiliki harus sama atau melebihi jumlah hutang maka akan lebih bagus jika rasio ini semakin kecil. Kemampuan perusahaan menghasilkan laba untuk menutupi hutang-hutangnya berhubungan dengan penggunaan dana yang berasal dari pemilik maupun yang bukan pemilik, termasuk penggunaan dana untuk melunasi dana obligasi dan pembayaran kembali pokok pinjaman (L.M.Samryn, S.E., Ak. 2015).

Menurut (Sujarweni 2017) Skala pengukuran yang digunakan untuk menilai laba bersih setelah pajak dan kemudian dipertimbangkan dengan volume penjualan dinamakan dengan Net Profit Margin. Melalui pengukuran rasio ini, dapat dilihat seberapa jauh daya saing perusahaan dalam memperoleh laba dengan segala kompetensi dan sumber daya perusahaan sebagaimana aktivitas dari penjualan, penerimaan kas, modal, jumlah karyawan serta jumlah cabang yang tersedia untuk menghasilkan profit yang tinggi. Rasio Net Profit Margin menunjukkan tingkat persentase laba bersih yang diperoleh dari setiap aktivitas penjualan perusahaan (Harahap 2016). Tingginya rasio ini menandakan bahwa perusahaan tersebut mampu meraih keuntungan yang besar selama periode tertentu. Menurut (L.M.Samryn, S.E., Ak. 2015) Net Profit Margin menunjukkan bahwa tiap rupiah penjualan yang dilakukan menghasilkan persentase laba yang dihasilkan setelah pajak atau untuk menghasilkan laba bersih setelah pajak diperlukan penjualan.

Berdasarkan hasil penelitian dari (Oktaviani 2016) menunjukkan current ratio dan net profit margin berpengaruh secara parsial terhadap harga saham, sedangkan debt to total asset ratio dan debt to equity ratio tidak berpengaruh terhadap harga saham. Hasil penelitian ini juga menyimpulkan bahwa current ratio, debt to total asset ratio, debt to equity ratio dan net profit margin berpengaruh secara simultan terhadap harga saham. Sedangkan penelitian yang dilakukan oleh (Tewal, Bin, and Jan 2017) menunjukkan bahwa secara parsial, current ratio dan debt to equity ratio tidak memiliki hubungan signifikan terhadap harga saham.

Hipotesis dalam penelitian ini dapat dirumuskan sebagai berikut:

H1: Terdapat signifikan antara current ratio dengan harga saham pada perusahaan food and beverage yang terdaftar di Bursa Efek Indonesia. 
$\mathrm{H} 2$ : Terdapat signifikan antara debt to total asset ratio dengan harga saham pada perusahaan food and beverage yang terdaftar di Bursa Efek Indonesia.

H3: Terdapat pengaruh signifikan antara debt to equity ratio dengan harga saham pada perusahaan food and beverage yang terdaftar di Bursa Efek Indonesia.

H4: Terdapat signifikan antara net profit margin dengan harga saham pada perusahaan food and beverage yang terdaftar di Bursa Efek Indonesia.

H5: Current Ratio, Debt to Total Asset Ratio, Debt to Equity Ratio, dan Net Profit Margin secara simultan berpengaruh signifikan terhadap harga saham pada perusahaan food and beverage yang terdaftar di Bursa Efek Indonesia.

\section{METODE}

Tujuan dari penelitian ini ialah untuk mengetahui apakah terdapat pengaruh antara current ratio, debt to total asset ratio, debt to equity ratio, dan net profit margin terhadap harga saham. Penelitian ini menggunakan populasi dari 18 perusahaan food and beverage yang terdaftar di Bursa Efek Indonesia. Metode pengambilan sampel yang digunakan dalam penelitian ini adalah dengan teknik Purposive Sampling. Penelitian ini menggunakan data sekunder dari 12 perusahaan yang dijadikan sebagai sampel penelitian dengan teknik pengumpulan data berupa metode studi pustaka dan metode dokumentasi. Analisis data dalam penelitian ini terdiri dari analisis statistik deskriptif, uji asumsi klasik, uji regresi linear berganda dan pengujian hipotesis.

\section{HASIL DAN PEMBAHASAN}

\section{Analisis Statistik Deskriptif}

Statistik deskriptif dapat diartikan sebagai salah satu cara yang disertai dengan teknik pengumpulan dan penyajian data untuk menghasilkan informasi yang berguna.

Tabel 1. Hasil Uji Statistik Deskriptif Descriptive Statistics

\begin{tabular}{llrrrr}
\hline & N & Minimum & Maximum & \multicolumn{1}{c}{ Mean } & Std. Deviation \\
\hline HargaSaham & 50 & 2,18 & 5,58 & 3,4975 &, 61097 \\
CR & 50 &,- 29 &, 94 &, 3026 &, 25478 \\
DAR & 50 &, 143076 &, 751778 &, 45766538 &, 152834592 \\
DER & 50 &, 166965 & 3,028644 &, 96918070 &, 549575958 \\
NPM & 50 & $-1,96$ &,- 41 & $-1,1191$ &, 37514 \\
Valid N (listwise) & 50 & & & & \\
\hline
\end{tabular}

Sumber: Hasil Penelitian, 2018 (Olah Data SPSS 21)

Tabel diatas menunjukkan bahwa variabel Harga Saham memiliki nilai minimum sebesar 2,18, nilai maksimum sebesar 5,58, mean sebesar 3,4975. Variabel Current Ratio memiliki nilai minimum sebesar -0,29, nilai maksimum sebesar 0,94, mean sebesar 0,3026. Variabel Debt to Total Asset Ratio memiliki nilai minimum sebesar 0,143076, nilai maksimum sebesar 0,751778, mean sebesar 0,45766538. Variabel Debt to Equity Ratio memiliki nilai minimum sebesar 0,166965, nilai maksimum sebesar 3,028644, mean sebesar 0,96918070. Variabel Net Profit Margin memiliki nilai minimum sebesar -1,96, nilai maksimum sebesar 0,41, mean sebesar $-1,1191$.

\section{Uji Normalitas}

Untuk membuktikan apakah data yang diuji berdistribusi normal atau tidak, dilakukan dengan uji normalitas. 
Tabel 2. Hasil Uji Normalitas

One Sample Kolmogorov-Smirnov Test

\begin{tabular}{llr}
\hline & & \multicolumn{2}{c}{$\begin{array}{c}\text { Unstandardized } \\
\text { Residual }\end{array}$} \\
\hline $\mathrm{N}$ & & 50 \\
Normal Parameters & Mean & $-36612,2802078$ \\
& Std. Deviation & 62498,71528191 \\
Most Extreme & Absolute &, 144 \\
Differences & Positive &, 144 \\
& Negative &,- 129 \\
Kolmogorov-Smirnov Z & & 1,018 \\
Asymp. Sig. (2-tailed) &, 251 \\
\hline a. Test distribution is Normal. & \\
b. Calculated from data. &
\end{tabular}

Sumber: Hasil Penelitian, 2018 (Olah Data SPSS 21)

Pada data table 2 diatas, dapat dilihat bahwa besarnya nilai kolmogorov-smirnov 1,018 dengan tingkat signifikan pada 0,251 . Jadi, nilai $p$-value $0,251>0,05$, hal itu berarti Ha diterima dan $\mathrm{H}_{0}$ ditolak sehingga terbukti bahwa data residual berdistribusi

\section{Uji Multikolinearitas}

Uji multikolinearitas bertujuan untuk menguji apakah terdapat korelasi antar variabel independen. Hasil uji multikolinearitas dapat dilihat pada tabel berikut ini:

Tabel 3. Hasil Uji Multikolinearitas

\begin{tabular}{clc}
\multicolumn{3}{c}{ Coefficients $^{\mathbf{a}}$} \\
\hline Model & $\begin{array}{c}\text { Collinearity Statistics } \\
\text { Tolerance }\end{array}$ & VIF \\
\hline 1 (Constant) & & \\
CR &, 289 & 3,463 \\
DAR &, 107 & 9,368 \\
DER &, 143 & 6,980 \\
NPM &, 768 & 1,301 \\
\hline a. Dependent Variable: HargaSaham \\
\hline
\end{tabular}

Sumber: Hasil Penelitian, 2018 (Olah Data SPSS 21)

Berdasarkan Tabel 3 menunjukkan angka tolerance pada semua variabel lebih dari 0,1 dan VIF yang kurang dari 10, maka dinyatakan tidak terjadi multikolineritas. Hal ini memperlihatkan bahwa tidak terjadi multikolonieritas atau hubungan yang sempurna atau mendekati sempurna sesama variabel independen dalam regresi.

\section{Uji Heteroskedastisitas}

Untuk menguji apakah model regresi terjadi ketidaksamaan variance dari residual pengamatan yang satu ke pengamatan yang lain dilakukan uji heteroskedastisitas. Model regresi yang baik adalah Homoskedastisitas atau tidak terjadi heteroskedastisitas yang artinya variance dari residual pengamatan yang satu ke pengamatan yang lain tetap atau tidak berbeda. 


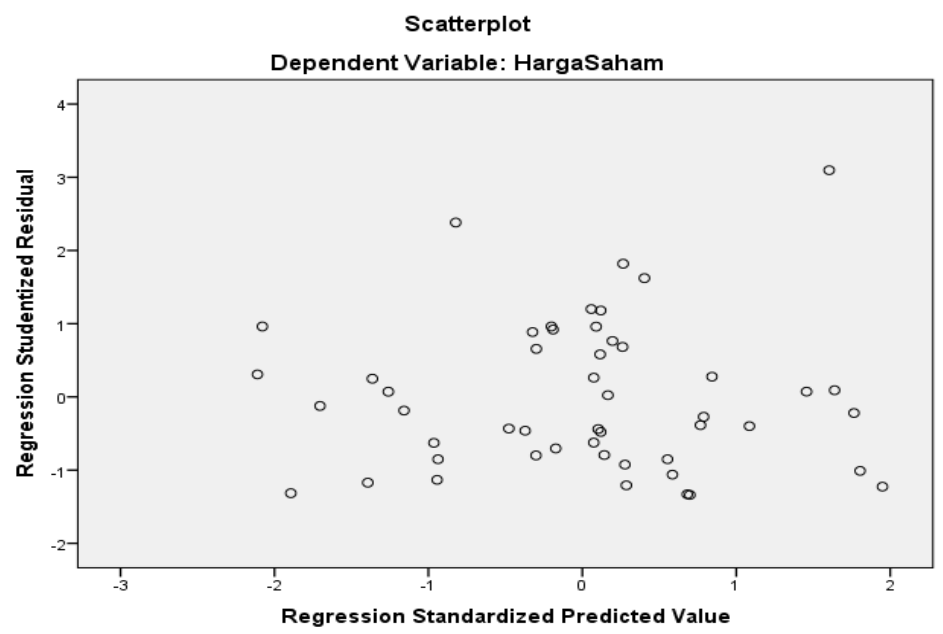

Gambar 1. Scatterplot

Sumber: Hasil Penelitian, 2018 (Olah Data SPSS 21)

Dari grafik scatterplots diatas, terlihat bahwa titik-titik data menyebar secara acak (random) baik diatas maupun diangka 0 pada sumbu Y. Hal ini menunjukkan bahwa tidak terjadi heteroskedastisitas pada model regresi

\section{Uji Autokorelasi}

Dalam model regresi linear, untuk mengetahui apakah ada korelasi antara kesalahan pengganggu pada periode t dengan periode t-1 dilakukan uji autokorelasi (Imam 2013)

\section{Tabel 4. Uji Autokorelasi \\ Model Summary}

\begin{tabular}{cccccc}
\hline Model & $\mathrm{R}$ & $\mathrm{R}$ Square & $\begin{array}{c}\text { Adjusted R } \\
\text { Square }\end{array}$ & $\begin{array}{c}\text { Std. Error of } \\
\text { the Estimate }\end{array}$ & Durbin-Watson \\
\hline 1 &, $608^{\mathrm{a}}$ &, 370 &, 314 &, 50608 & 1,570 \\
a. Predictors: (Constant), NPM, DER, CR, DAR & &
\end{tabular}

b.Dependent Variabel: Harga Saham

Sumber: Hasil Penelitian, 2018 (Olah Data SPSS 21)

Berdasarkan hasil pengujian autokolerasi pada tabel 4 diatas, nilai Durbin Watson 1,570 berada diantara angka -2 sampai dengan $+2(-2<1,570>+2)$ yang menandakan bahwa model regresi tidak terjadi autokolerasi. 


\section{Uji Secara Simultan (Uji F)}

Uji parsial digunakan guna menggambarkan seberapa jauh variabel-variabel independen secara bersamaan mempengaruhi variabel dependen. Hasil uji pengaruh secara simultan diuraikan dalam tabel di bawah ini:

Tabel 5. Hasil Uji Secara Simultan (Uji F)

\begin{tabular}{llrrrrr}
\multicolumn{7}{c}{ ANOVA $^{\mathbf{a}}$} \\
\hline Model & & Sum of Squares & df & Mean Square & F & Sig. \\
\hline 1 & Regression & 6,766 & 4 & 1,691 & 6,604 &, $000^{\circ}$ \\
& Residual & 11,525 & 45 &, 256 & & \\
& Total & 18,291 & 49 & & & \\
\hline
\end{tabular}

a. Dependent Variable: HargaSaham

b. Predictors: (Constant), NPM, DER, CR, DAR

Sumber: Hasil Penelitian, 2018 (Olah Data SPSS 21)

Berdasarkan tabel 5 diatas, diketahui nilai $\mathrm{F}_{\text {hitung }}>\mathrm{F}_{\text {tabel }}(6,604>2,58)$ dan tingkat signifikansi sebesar 0,000 maka keputusan $\mathrm{H}_{5}$ diterima yaitu variabel Current Ratio, Debt to Total Asset Ratio, Debt to Equity Ratio, dan Net Profit Margin secara simultan berpengaruh terhadap harga saham pada perusahaan food and beverage yang terdaftar di Bursa Efek Indonesia periode 2013-2017.

\section{Uji Secara Parsial (Uji T)}

Dalam menguji bagaimana pengaruh masing-masing variabel independen terhadap variabel dependen dilakukan uji parsial. Cara pengujiannya dilakukan dengan membandingkan $t_{\text {hitung }}$ dengan $t_{\text {tabel }}$.

Tabel 6. Hasil Uji Secara Parsial (Uji T)

\begin{tabular}{lrrrrr}
\multicolumn{7}{c}{ Coefficients $^{\mathbf{a}}$} \\
\hline Model & \multicolumn{2}{c}{$\begin{array}{c}\text { Unstandardized } \\
\text { Coefficients } \\
\text { Std. Error }\end{array}$} & $\begin{array}{c}\text { Standardized } \\
\text { Coefficients } \\
\text { Beta }\end{array}$ & $\mathrm{t}$ & Sig. \\
& \multicolumn{1}{c}{ B } &, 576 & & 7,490 &, 000 \\
\hline (Constant) & 4,317 &, 528 &, 135 &, 612 &, 544 \\
CR &, 323 & 1,448 &,- 010 &,- 026 &, 979 \\
DAR &,- 038 &, 348 &, 149 &, 478 &, 635 \\
DER &, 166 &, 220 &, 582 & 4,313 &, 000 \\
\hline
\end{tabular}

a. Dependent Variabel: Harga Saham

Sumber: Hasil Penelitian, 2018 (Olah Data SPSS 21)

Dari tabel 6 diatas, dapat diinterpretasikan bahwa Variabel Current Ratio memiliki $\mathrm{t}_{\text {hitung }}$ $0,612<\mathrm{t}_{\text {tabel }} 1,68023\left(\mathrm{t}_{\text {tabel }} \alpha=0.05, \mathrm{df}=(50-5-1)=44\right)$ dengan signifikansi $0.544>\alpha=0.05$, maka $\mathrm{H}_{1}$ ditolak menunjukkan bahwa secara parsial variabel Current Ratio tidak berpengaruh terhadap harga saham. Variabel Debt to Total Asset Ratio memiliki $\mathrm{t}_{\text {hitung }}-0,026<\mathrm{t}_{\text {tabel }}-1,68023$ $\left(\mathrm{t}_{\text {tabel }} \alpha=0.05\right.$, df $\left.=(50-5-1)=44\right)$ dengan signifikansi $0.979>\alpha=0.05$, maka $\mathrm{H}_{2}$ ditolak menunjukkan bahwa secara parsial variabel Debt to Total Asset Ratio tidak berpengaruh terhadap harga saham. Variabel Debt to Equity Ratio memiliki $\mathrm{t}_{\text {hitung }} 0,478<\mathrm{t}_{\text {tabel }} 1,68023(\alpha=$ $0.05, \mathrm{df}=(50-5-1)=44)$ dengan signifikansi $0.635>\alpha=0.05$, maka $\mathrm{H}_{3}$ ditolak menunjukkan bahwa secara parsial variabel Debt to Equity Ratio tidak berpengaruh terhadap harga saham. Variabel Net Profit Margin memiliki $t_{\text {hitung }} 4.313>\mathrm{t}_{\text {tabel }} 1,68023(\alpha=0.05, \mathrm{df}=(50-5-1)=44)$ dengan signifikansi $0.000<\alpha=0.05$, maka $\mathrm{H}_{4}$ diterima menunjukkan bahwa secara parsial variabel Net Profit Margin berpengaruh signifikan positif terhadap harga saham. 


\section{Uji Koefisien Determinasi}

Teknik yang dapat digunakan untuk menilai seberapa jauh kemampuan model menerangkan variansi dari variabel independen yaitu dengan uji koefisien determinasi. Nilai koefisien determinasi berada di antara nol atau satu. Hasil pengujian koefisien determinasi (R2) ditunjukkan pada table berikut ini:

Tabel 7. Hasil Uji Koefisien Determinas

Model Summary ${ }^{\text {b }}$

\begin{tabular}{cccccc}
\hline Model & $\mathrm{R}$ & R Square & $\begin{array}{c}\text { Adjusted R } \\
\text { Square }\end{array}$ & $\begin{array}{c}\text { Std. Error of } \\
\text { the Estimate }\end{array}$ & Durbin-Watson \\
\hline 1 &, $608^{\mathrm{a}}$ &, 370 &, 314 &, 50608 & 1,570
\end{tabular}

a. Predictors: (Constant), NPM, DER, CR, DAR

b.Dependent Variabel: Harga Saham

Sumber: Hasil Penelitian, 2018 (Olah Data SPSS 21)

Dari tabel 7 diatas dapat dilihat nilai koefisien determinasi (R2) sebesar 0,370 atau 37\% dari variabel Current Ratio, Debt to Total Asset Ratio, Debt to Equity Ratio, dan Net Profit Margin, sedangkan sisanya 63\% dipengaruhi oleh variabel lain yang tidak dicantumkan dalam model penelitian.

\section{SIMPULAN}

Kesimpulan yang dapat ditarik sebagai pembuktian atas hipotesis yang diajukan dari hasil analisis diatas adalah:

1. Hasil penelitian menunjukkan bahwa variabel Current Ratio tidak berpengaruh terhadap harga saham. Hal ini dilihat pada nilai signifikan 0,544 > 0,05 sehingga hipotesis pertama yang menyatakan bahwa Current Ratio berpengaruh signifikan terhadap harga saham ditolak, hal ini sejalan dengan penelitian terdahulu yang dilakukan oleh (Tewal, Bin, and Jan 2017), (Krisnadwipayana, Ekonomi, and Jakarta 2018) yang menyatakan bahwa Current Ratio tidak berpengaruh terhadap harga saham. Namun hasil penelitian ini tidak sejalan dengan penelitian terdahulu yang dilakukan oleh (Oktaviani 2016) yang menyatakan bahwa Current Ratio berpengaruh positif dan signifikan terhadap harga saham mungkin karena jumlah sampel yang digunakan berbeda dengan jumlah sampel yang digunakan dalam penelitian ini.

2. Hasil penelitian menunjukkan bahwa variabel Debt to Total Asset Ratio tidak berpengaruh terhadap harga saham. Hal ini dilihat pada nilai signifikan 0,979>0,05 sehingga hipotesis kedua yang menyatakan bahwa Debt to Total Asset Ratio berpengaruh signifikan terhadap harga saham ditolak, hal ini sejalan dengan penelitian terdahulu yang dilakukan oleh (Oktaviani 2016) bahwa Debt to Total Asset Ratio tidak berpengaruh terhadap harga saham.

3. Hasil penelitian menunjukkan bahwa variabel Debt to Equity Ratio tidak berpengaruh terhadap harga saham. Hal ini dilihat pada nilai signifikan 0,635>0,05 sehingga hipotesis ketiga yang menyatakan bahwa Debt to Equity Ratio berpengaruh signifikan terhadap harga saham ditolak, hal ini sejalan dengan penelitian terdahulu yang dilakukan oleh (Kamar 2017), (Tewal, Bin, and Jan 2017), (Amalya 2018), (Oktaviani 2016), (Junaeni 2017) bahwa Debt to Equity Ratio tidak berpengaruh terhadap harga saham. Namun, hal ini tidak sejalan dengan penelitian terdahulu yang dilakukan oleh (Suparningsih 2017), (Kristanti and Sutono 2016) yang menyatakan bahwa Debt to Equity Ratio berpengaruh terhadap harga saham mungkin karena lokasi penelitian yang berbeda dan jumlah sampel yang digunakan juga berbeda dengan jumlah sampel dalam penelitian ini. 
4. Hasil penelitian menunjukkan bahwa variabel Net Profit Margin berpengaruh signifikan terhadap harga saham. Hal ini dilihat pada nilai signifikan $0,000<0,05$ sehingga hipotesis keempat yang menyatakan bahwa Net Profit Margin berpengaruh signifikan terhadap harga saham diterima, hal ini sejalan dengan penelitian terdahulu yang dilakukan oleh (Oktaviani 2016), (Suparningsih 2017), (Tewal, Bin, and Jan 2017), (Amalya 2018) bahwa Net Profit Margin berpengaruh signifikan terhadap harga saham.

5. Hasil penelitian menunjukkan bahwa variabel Current Ratio, Debt to Total Asset Ratio, Debt to Equity Ratio, dan Net Profit Margin secara simultan berpengaruh signifikan terhadap harga saham. Hal ini dilihat pada nilai signifikan $0,000<0,05$ sehingga hipotesis kelima yang menyatakan bahwa Current Ratio, Debt to Total Asset Ratio, Debt to Equity Ratio, dan Net Profit Margin secara simultan berpengaruh signifikan terhadap harga saham diterima. Hal ini sejalan dengan penelitian terdahulu yang dilakukan oleh Yeni Oktaviani (2018) bahwa Current Ratio, Debt to Total Asset Ratio, Debt to Eauity Ratio, dan Net Profit Margin secara simultan berpengaruh signifikan terhadap harga saham.

\section{DAFTAR PUSTAKA}

Amalya, Neneng Tita. 2018. "Pengaruh Return On Asset, Return On Equity, Net Profit Margin Dan Debt To Equity Ratio Terhadap Harga Saham." 1(3): 157-81.

Harahap, Sofyan Syafri. 2016. Analisis Kritis Atas Laporan Keuangan. 1st ed. Jakarta: Rajawali Pers.

Hery S.E., M.Si., RSA., CRP. 2015. Pengantar Akuntansi. Jakarta: PT Grasindo.

Imam, Ghozali. 2013. Aplikasi Analisis Multivariate Dengan Program IBM SPSS 21 Update PLS Regresi. Semarang: Badan Penerbit Universitas Diponegoro.

Jogiyanto, H.M. 2010. Teori Portofolio Dan Analisis Investasi. 7th ed. Yogyakarta: BPFE.

Junaeni, Irawati. 2017. "Pengaruh EVA, ROA, DER Dan TATO Terhadap Harga Saham Pada Perusahaan Makanan Dan Minuman Di BEI." Pengaruh EVA, ROA, DER dan TATO terhadap Harga Saham pada Perusahaan Makanan dan Minuman di BEI 2.

Kamar, Karnawi. 2017. "Analisis Pengaruh Return on Equity ( Roe ) Dan Debt to Equity Ratio ( Der ) Pada Harga Saham Pada Industri Semen Listed In Bursa Efek Indonesia ( BEI ) Pada Tahun 2011-2015." Analisis Pengaruh Return on Equity ( Roe ) dan Debt to Equity Ratio ( Der ) Pada Harga Saham pada Industri Semen Listed In Bursa Efek Indonesia ( BEI) Pada Tahun 2011-2015 19(5): 66-76.

Krisnadwipayana, Ekonomi Universitas, Dosen Fakultas Ekonomi, and Universitas Krisnadwipayana Jakarta. 2018. "Effect Of Current Ratio, Leverage Ratio, Inflation and Currency Share Closing Price Of Consumer Goods Industry In Indonesia Stock Exchange." (2001): 41-53.

Kristanti, Novia, and Sutono. 2016. "Pengaruh Earning Per Share, Return On Equity Dan Debt To Equity Ratio Terhadap Harga Saham Pada Food and Beverages Yang Terdaftar Di Bursa Efek Indonesia." (44).

L.M.Samryn, S.E., Ak., M.M. CA. 2015. Pengantar Akuntansi. 4th ed. Jakarta: Rajawali Pers.

Oktaviani, Yeni. 2016. "Pengaruh Current Ratio (CR), Debt To Total Assets Ratio (DAR), Debt To Equity Ratio (DER), Dan Net Profit Margin (NPM) Terhadap Harga Saham Pada Perusahaan Food and Beverages Yang Terdaftar Di Bursa Efek Indonesia Periode 20132016." Pengaruh Current Ratio (CR), Debt To Total Assets Ratio (DAR), Debt To Equity Ratio (DER), Dan Net Profit Margin (NPM) Terhadap Harga Saham Pada

Perusahaan Food and Beverages Yang Terdaftar di Bursa Efek Indonesia Periode 2013-2016: $1-17$.

Sujarweni, V.Wiratna. 2017. Analisis Laporan Keuangan: Teori, Aplikasi Dan Hasil Penelitian. Yogyakarta: Pustaka Baru Press.

Suparningsih, Budhi. 2017. "Effect of Debt to Equity Ratio ( DER ), Price Earning Ratio ( PER ), Net Profit Margin ( NPM ), Return on Investment ( ROI ), Earning per Share ( EPS ) In Infulence Exchange Rates and Indonesian Interest Rates ( SBI )Effect of Debt to Equity Ratio ( DER )." 4(58): 58-62. 
Tewal, Bernhard, Arrazi Bin, and Hasan Jan. 2017. "Pengaruh Current Ratio, DER, ROA DAN NPM Terhadap Harga Saham Pada Perusahaan Food and Beverages Yang Terdaftar Di BEI (Periode 2013-2015)." 5(2): 1813-22.

Zuliarni, S. 2012. "Pengaruh Kinerja Keuangan Terhadap Harga Saham Pada Perusahaan Mining Dan Mining Service Di Bursa Efek Indonesia." In , 36-48 